\title{
HISTORY OF MATHEMATICS \\ EDUCATION IN PRIMARY SCHOOL AND IN TEACHER TRAINING IN BRAZIL
}

\author{
Wagner Rodrigues Valente ${ }^{1}$ \\ Maria Célia Leme da Silva²
}

\section{ABSTRACT}

This article discusses results from research developed on the transformations in mathematics teaching in primary school and the mathematics in teacher training from the $19^{\text {th }}$ century to the mid-20 $0^{\text {th }}$ century in Brazil. We have analyzed the understanding of the relationship between the mathematical disciplinary field and pedagogy in order to confirm the theoretical hypothesis that the interactions between the two fields produce mathematics of different natures, which are interconnected.

Keywords: teacher training, primary school, mathematics to teach, mathematics for teaching, intuitive method, Progressive Education.

\footnotetext{
${ }^{1}$ Universidade Federal de São Paulo - Campus Guarulhos (Unifesp), Guarulhos/SP, Brasil.

${ }^{2}$ Universidade Federal de São Paulo - Campus Diadema (Unifesp), Diadema/SP, Brasil.
} 


\section{HISTÓRIA DA EDUCAÇÃO MATEMÁTICA NO CURSO PRIMÁRIO E FORMAÇÃO DE PROFESSORES NO BRASIL}

\section{RESUMO}

O artigo sintetiza resultados de pesquisas que vêm sendo desenvolvidas sobre as transformações do ensino de matemática para o curso primário e a matemática presente na formação de professores, desde o século XIX até meados do século XX no Brasil. Problematiza-se o entendimento das relações entre o campo disciplinar matemático e a pedagogia, confirmando a hipótese teórica de que as articulações entre os dois campos produzem matemáticas de naturezas diferentes e articuladas entre si.

Palavras-chave: formação de professores; curso primário, matemática a ensinar; matemática para ensinar, método intuitivo, Escola Nova.

\section{HISTORIA DE LA EDUCACIÓN MATEMÁTICA EN LA ESCUELA PRIMARIA Y FORMACIÓN DOCENTE EN BRASIL}

\section{RESUMEN}

El artículo resume los resultados de la investigación que se ha desarrollado sobre las transformaciones de la enseñanza de las matemáticas para la escuela primaria y las matemáticas presentes en la formación docente, desde el siglo XIX hasta mediados del siglo XX en Brasil. La comprensión de las relaciones entre el campo disciplinario matemático y la pedagogía se problematiza, lo que confirma la hipótesis teórica de que las articulaciones entre los dos campos producen matemáticas de diferentes naturalezas y articuladas entre sí.

Palabras clave: formación docente, escuela primaria, matemáticas a enseñar, matemáticas para enseñar, método intuitivo, Nueva Escuela.

\section{HISTOIRE DE L'ENSEIGNEMENT MATHÉMATIQUE À L'ÉCOLE PRIMAIRE ET FORMATION DES ENSEIGNANTS AU BRÉSIL}

\section{RÉSUMÉ}

L'article résume les résultats des recherches développées sur les transformations de l'enseignement des mathématiques à l'école primaire et des mathématiques présentes dans la formation des enseignants du Brésil du XIXe au milieu du XXe siècle. La compréhension des relations entre le champ disciplinaire mathématique et la pédagogie est problématique, confirmant l'hypothèse théorique selon laquelle les articulations entre les deux champs produisent des mathématiques de natures différentes et articulées l'une avec l'autre.

Mots-clés: formation des enseignants, école primaire, mathématiques à enseigner, mathématiques pour enseigner, méthode intuitive, Nouvelle École. 


\section{INTRODUCTION}

Studying the history of mathematics education in primary school and in teacher training has the goal of stressing the changes that happened from the middle of the $19^{\text {th }}$ century until the first decades of the $20^{\text {th }}$ century in two forms of mathematical knowledge that are part of primary school. The first form concerns mathematics to teach, which is understood as the teaching object of professionals who teach in the first years of primary school (BERTINI; MORAIS; VALENTE, 2017). It refers to the mathematics related to teaching, the mathematics existing in official documents, in teaching programs and in all sorts of references that indicate what and how teachers should teach in primary school when it comes to mathematics teaching practices.

Studies on the history of school disciplines, like the ones conducted by André Chervel (1990), reveal the complexity behind the elaboration of the knowledge harnessed in teaching. Based on Chervel, we consider that mathematics to teach should be analyzed in its historical process of elaboration, which includes studying the dynamics of relationships and struggles over representation (CHARTIER, 1990) between the subject field - in this case, mathematics - and the pedagogical field - the education sciences.

On the other hand, regarding the training of teachers who teach mathematics in primary school, we consider the existence of other type of mathematics. That is, the type of mathematics existing in teacher training in order to empower future teachers for the professional practice of teaching. Such mathematics is called mathematics for teaching (BERTINI; MORAIS; VALENTE, 2017), a working tool that must be part of teacher training. By acquiring it, future primary school teachers are able to teach mathematics.

Thus, this article analyzes the transformation processes of mathematics to teach and mathematics for teaching for the production of a history of 
mathematics education in primary school and in teacher training, based on results from collective research conducted under the supervision of the authors of this study3.

\section{ARITHMETIC IN TEACHING AND IN TEACHER TRAINING}

Studies have shown that the training process of educators who teach mathematics (arithmetic) was - at least until the final decades of the $19^{\text {th }}$ century - focused on the subject field (VALENTE, 2011). Thus, teacher training included arithmetic subjects that were identical to those of secondary school, without any specificities or orientations that connected said subjects with the teaching needs that were specific from the early years of primary school.

Nevertheless, there were progressive modifications in teacher training disciplines with focus on professional teaching practice. From 1880, the presence of the intuitive methodology 4 in education increasingly generated tension between teacher training and teaching, which was supposed to be performed intuitively, according to the progressive education trend that was being established internationally as supported by Pestalozzi, Fröebel and other authors.

\footnotetext{
3 Namely the following projects: "Mathematics in teacher training and in teaching: processes and dynamics of production of professional knowledge, 1890-1990" (Fapesp - theme project), "Mathematics in primary school in the $19^{\text {th }}$ and $20^{\text {th }}$ centuries: comparative studies between Brazil and France" (Capes/Cofecub), "Transformations of geometric knowledge in Brazilian primary school" (Fapesp) (free translations).

4 "The intuitive teaching method had a widespread presence, in the second half of the $19^{\text {th }}$ century, in countries in Europe and in the Americas, as the main element of renewal of teaching, as well as of teacher training. [...] The historical roots of intuitive teaching are linked to the decline of scholastic teaching and to the rise of modern pedagogy notions proposed by Bacon, Comenius, Rabelais, Locke, Condilac, Rousseau, Pestalozzi, Basedow, Campe, Fröebel and others. As opposed to teaching based solely on books, intuitive teaching stems from the notion that education must start with educating the senses" (part of the entry written by Analete Regina Schelbauer, professor in the Department of Education Theory and Practice and in the Postgraduate Program of Education at Universidade Estadual de Maringá, in the state of Paraná, Brazil. She is a researcher and member of HistedBr - GT, Maringá, Brazil).
} 
The continuous movement of teaching professionalization produced new knowledge for teacher training as a result of the tension between the subject fields - secondary school subjects were the model for teacher training and modern pedagogy, which was fed by the intuitive methodology5. Specifically, the mathematics approached in teacher training underwent changes, and mathematics for teaching, which is a working tool for teaching practice, was historically configured. Consequently, in the scope of mathematics for teaching, especially, arithmetic for teaching emerged.

Since the mid- $19^{\text {th }}$ century, with secondary school as a reference, teacher training courses saw the use of arithmetic books that involved the numbering system, arithmetic operations, fractions, decimal numbers, ratio, proportion, etc., clarifying the organization of arithmetic to teach. Such content was supposed to train future mathematics (arithmetic) teachers ${ }^{6}$. The logic behind such formation was the same as the one that organized arithmetic subjects; it followed arithmetic content internal ordering. How to teach, who to teach, when to teach and where to teach such arithmetic are questions that were not relevant to teacher trainers' work, for training referred to the mastering of mathematical content - the arithmetic content that was the reference for training courses. In other words, it was the same content as the one existing in the secondary course (VALENTE, 2011).

The intuitive methodology would alter such identity from arithmetic to be taught by future teachers - arithmetic to teach - to arithmetic to train teachers - arithmetic for teaching. It is necessary to highlight a new paradigm established by education philosophers from the past, like Pestalozzi, Fröebel and others, as mentioned previously. From a new perspective, it was stressed that teaching was supposed to be in conformity with the way students learned, and the first steps in mathematics were learned intuitively. The intuitive

5 For further studies on the progressive movement of teaching professionalization, see Hofstetter; Valente (2017).

6 As an example, we suggest Compêndio de Aritmética (Arithmetic Compendium, in free translation) by Cristiano Benedito Ottoni, which had several editions in the second half of the $19^{\text {th }}$ century (VALENTE, 2011). 
methodology caused tension and discussions for changes in teacher training (VALENTE, 2011). At last, teaching practice demanded more specificity and more professionality, for teachers were supposed to be trained with the advancements of education in mind, that is, according to modern pedagogy. Training had to leave behind the concept of a general and broad culture; there had to be modifications focusing on a professional culture of teaching. New teaching professionals were supposed to have new professional knowledge. Instead of providing them with training that was identical to that of secondary school - subject/discipline training -, it was imperative to promote a connection between what had to be taught and future teachers' training.

It is important to take into account that the end of the $19^{\text {th }}$ century is considered the time when the first practices of expertise occurred in the pedagogical field. They were performed by people who participated in school life, that is, "good men" who would become professionals and conduct specific research, experiment with new methods, establish the premises of the Education Science subject field (HOFSTETTER et al., 2017).

Complex processes have historically shown how a new arithmetic was organized at the time of the intuitive trend. Intuitive arithmetic, new knowledge to be taught in the first primary school years, was then configured. Said arithmetic would become new knowledge to teach, arithmetic to teach, intuitive arithmetic to teach.

Studies like the one conducted by Oliveira (2017) investigated the characteristics that consolidated intuitive arithmetic as mathematics to be present in teaching, that is, mathematics to teach, arithmetic to teach. The author conducted an extensive analysis of a set of textbooks from that historical period and, as a result, he was able to characterize intuitive arithmetic.

[...] intuitive arithmetic from modern pedagogy left behind the concept that considered arithmetic a type of knowledge exclusive to school. Previously, daily-life issues were almost never approached and, when they were approached, they constituted separate tasks. With 
modern pedagogy, such new knowledge inverted the logic, for it was not intended to be taught through real-life situations. From then on, there was the indication to structure contents by relating children's social lives to school life - a way through which students could learn and apprehend Arithmetic through its natural application in their real needs. Thus, Arithmetic became a subject that provided children with an opportunity to apply what they learned at school in their social lives; a subject that extracted, from social life, situations to compose and conduct school-life tasks (OLIVEIRA, 2017, p. 245-246).

With the characterization of intuitive arithmetic, which was in effect from the final decades of the $19^{\text {th }}$ century and consolidated in the first decades of the $20^{\text {th }}$ century, teacher training courses - especially normal schools produced knowledge to teach said new discipline. Therefore, new arithmetic for teaching was developed for future teachers' training, and it was different from the one contained in arithmetic treatises, which were the references for secondary courses. New arithmetic for teaching would appear on the pages of teaching manuals as references for the training provided by normal schools.

In the beginning of modern pedagogy under the intuitive methodology, pedagogy compendiums, like the ones written by Antônio Pontes, whose first edition was published in 1873 , started to circulate around normal schools. The author was a lifelong teacher at Escola Normal do Rio de Janeiro (Rio de Janeiro Normal School, in free translation) and also its principal. On the more than two hundred pages contained in his book, we find what can be called arithmetic for teaching.

In the orientations to future teachers, the author stated that they were supposed to consider that the beginning of the pedagogic work must approach the necessity of harnessing an important type of knowledge: oral calculations, which are calculations made in a verbalized way. Such process was far from the tradition imposed by school, which made use of memory. Teaching how to make calculations orally, without memorization, was new professional knowledge. After all, children did not even know how to read or write. First, the objects had to be presented to the children and considered devices at the service of 
intuition, so the teacher was supposed to be able to teach according to the intuitive method.

Another type of professional knowledge that was highlighted in the compendium was the different treatment arithmetic operations were supposed to receive. The teacher had to know how to go beyond the traditional memorization of the multiplication table. To do so, professionally, the teacher had to know how to teach mental calculations, and to be able to teach mental calculations, the teacher first had to encourage students to make intuitive calculations through empirical objects.

In other words, firstly teachers were supposed to teach operations by using objects that were part of students' universe, then repeat them and consequently, with effort and habit, the results of such work would be trusted to memory. The operations would be more easily memorized if teaching occurred through intuitive processes. Memory would be established by understanding the operations with concrete objects, not because the student had been led to memorize the multiplication table. As can be seen, this type of knowledge is very different from the knowledge that was traditionally commonplace in teachers' practices (MACIEL; VALENTE, 2018).

Pedagogical manuals, like the ones by Pontes (1873), in addition to expressing pedagogical notions from the time when they were published - i.e. the intuitive method -, provided teachers with a systematization of knowledge for training, showing how to approach the different disciplines that were part of primary school. According to the terminology that we are using in this article, pedagogical manuals systematized knowledge for teaching. When they approached mathematics (arithmetic, geometry, drawing, etc.), they expressed mathematics for teaching, which is a future teacher's working tool.

In the emergence of the movement called Progressive Education - a movement of different teaching trends which, as a whole, advocated a more scientific approach to education, encouraged by the advances obtained by statistically based experimental psychology -, new works arose in order to 
empower teachers for the teaching of a new arithmetic: tailor-made arithmetic (PINHEIRO, 2017).

At the time when Progressive Education was prominent, scientific knowledge had the authority to propose and advocate proper solutions to educational problems, that is, the answers to such problems were supposed to emerge from laboratories. By stressing how teaching was scientifically supposed to occur in order to make it efficient, scientific pedagogy - an important branch of Progressive Education - reorganized the contents of school subjects, especially of arithmetic, so that their serialization, teaching organization and sequence met the statistically based results prospected from the psychological and pedagogical tests conducted by experimental psychology. Psychological tests assessed students' maturity in the beginning of the school process, in the organization of the first grades, whereas pedagogical (diagnostic) tests, done throughout the learning period, particularly helped with teaching practice in choosing appropriate methods - considered remedies - to solve problems, to improve students' performance and teaching efficiency (PINHEIRO, 2017).

Therefore, unlike the pedagogical methodology that preceded it intuitive pedagogy -, scientific pedagogy did not preserve the logical organization of school subjects, modifying teaching methods only. Instead of the traditional order of school content organization with a new method, a new order would be suitable - the psychological content order, which configurated a tailormade arithmetic (PINHEIRO, 2017). Consequently, new arithmetic to teach was shaped, conformed by tailor-made arithmetic.

Thus, arithmetic teaching would undergo changes. When the individual that learns was considered in arithmetic teaching, the hypothesis that the four fundamental operations had difficulties inherent to each one of them was confirmed, which required a systematization of what was supposed to be taught in each school age. It was not an alteration in the presentation order of each operation - the traditional sequence of teaching with addition first, then subtraction, multiplication and finally division -, but an alteration in the 
learning order of certain arithmetic combinations, having in mind that the combination order modified the difficulty level of teaching the operations. From a psychological point of view, teaching, for instance, $6+9$ was not the same as teaching $9+6$, for the first number combination was much more difficulty for children than the second one.

Furthermore, the operations could not be learned simultaneously anymore, as in the teaching methodology that became known as "Grube's method", a German teacher who advocated the intuitive method. Each operation had to be taught separately, then the knowledge acquired was the starting point for the acquisition of a new operation. Students would no longer learn the multiplication table of an operation before they had learned all the combinations separately. The logical order of ascending arrangement of the several combinations that constituted the multiplication table had to be altered. The new arrangement had to meet a new arrangement logic, a psychological order that aimed at making the acquisition of mathematical knowledge easier, with the main goal of performing operations faster and more precisely (PINHEIRO, 2017).

It is possible to state that, in order to meet the demand from tailormade arithmetic, scientific pedagogy generated arithmetic for teaching, whose focus was not on how, but in the order through which exercises related to arithmetic operations were supposed to be taught. We are not discussing a type of mathematics (arithmetic) pedagogy that teachers had to pay attention to and make use of in their practice; on the contrary, teachers needed to use precise sequences - considered scientific - in the serialization of arithmetic problems and exercises. Following a step-by-step guide to meticulously selected and organized exercises would guarantee the efficiency of teaching. Such considerations may be translated as mathematics for teaching systematized by one of the most popular authors of his time in terms of number of editions and circulation of his teacher training pedagogical manuals: Miguel Aguayo (SILVA, 2005). 
Aguayo is the author of Pedagogia científica: psicologia e direção da aprendizagem (Scientific pedagogy: psychology and learning management, in free translation), published in 1936. In the book, the author tells teachers that arithmetic was supposed to aim at practical teaching. Understanding the meaning of practical teaching in arithmetic was connected with the need to make students perform arithmetic operations fast and correctly. To do so, teachers were supposed to pay attention to the role of exercise sequencing. Teachers were not free to suggest - without scientific references - a given set of exercises about a given operation. In order to achieve the intended result, it was necessary to consider studies that had already been conducted and sequences already established by pedagogical tests, which were done according to statistical measurement.

Therefore, it is possible to say that, in this case, experiments were generators of professional knowledge for educators who teach mathematics because they were supposed to indicate a working order for teachers; they were real instruments for such professionals, which made them arithmetic for teaching.

In addition, we assume that if, on the one hand, scientific pedagogy produced arithmetic that was particular to school and, as a consequence, arithmetic to teach - tailor-made arithmetic, based mainly on tests -, on the other hand, connected to such arithmetic, the experimental method was responsible for a type of arithmetic that was particular to teaching - arithmetic for teaching. What are the main characteristics of such arithmetic as a professional tool, as teachers' professional knowledge of arithmetic for the first years of primary school?

Differently from previous times - when teachers could, to a certain extent, choose and create exercises to be solved by their students, based on previously explained topics -, such concept underwent changes. The new pedagogy - scientific pedagogy - demanded a new professional attitude from teachers. To teach arithmetic in primary school, teachers had to be updated on 
the results from scientific studies promoted by statistically based experimental psychology. In practical terms, future teachers were supposed to consider tables and sequences of exercises which would be solved by students step by step and allow them to learn practical arithmetic, that is, a type of arithmetic through which they would be able to perform calculations with the four fundamental operations fast and precisely. Such sequences stemmed from mental and pedagogical tests and constituted a tested and approved instrument to be put to use by future teachers.

Throughout its historical journey, education saw the emergence of modern intuitive pedagogy, then it advanced to Progressive Education and the scientific character of its educational propositions. After that, mathematics saw the New Math movement arise. In each of those historical moments with such different pedagogies and transformations in subject fields, different relations were established between the pedagogical field and the scientific subjects. Such relations promoted the elaboration of new knowledge: knowledge for teaching and knowledge to teach, that is, mathematics for teaching and mathematics to teach. Studying the changes in arithmetic for teaching revealed the changes in the professional knowledge of educators who teach mathematics.

\section{GEOMETRY AND DRAWING IN TEACHING AND IN TEACHER TRAINING}

The $19^{\text {th }}$ century is considered the cradle of a new geometry both as school knowledge - particular to teaching - and professional knowledge teachers' working tools. From the point of view of teaching, it was born as practical geometry, with the goal of fulfilling the needs relating to rural fields, as measurement calculation practices (LEME DA SILVA; VALENTE, 2014).

However, studies have shown that when practical geometry entered schools as a pedagogical activity, it changed its initial purpose and transformed into practical geometry, which was connected to the exercise of observation, of 
watching measurements and forms and reproducing drawings of geometric figures by hand 7 . One of the first school manuals ${ }^{8}$ to guide Brazilian geometry teaching was the book by Francœur (1819)9, which was translated into and adapted to Portuguese. Therefore, the practical character of rural activities, like land measurements, migrates to a drawing practice - building lines, angles, flat figures and even perspective drawings of geometric solids. Such school geometry was constituted as free hand drawing.

With such geometry of teaching - geometry to teach -, when it comes to teacher training, there was the prominence of school manuals as guides for the practice of teaching geometry in the period of creation of the first teacher training schools. It is possible to say that manuals that indicated procedures, teaching methods, supporting materials, organization and suggestions on activities to be used in geometry teaching and tools that subsidized teaching practice were very rare and few. In other words, manuals contained elements that configured geometry for teaching, having in mind that, throughout the $19^{\text {th }}$ century, teacher training in Brazil was incipient.

The characteristic of reproduction and copy of models (geometric figures) from observation constituted the teaching methodology of the first Brazilian translations and adaptations, as a "force of imitation", in which teachers did not provide students with any orientations. The drawing produced was the result of training students' hands for outlines and training their observation for the practice of measuring (LEME DA SILVA; VALENTE, 2014; OLIVEIRA, 2019).

\footnotetext{
7 Read works by Valente (2012) and Leme da Silva \& Valente (2014).

${ }^{8}$ According to Choppin (2009), "today, the terms to which different languages resort to express the concept of schoolbook are still multiple, and their meaning is not precise" (p. 19). Thus, in this chapter, we call manuals all books that bring teaching guidance for teachers or monitors (in the case of the monitorial system), activities to be developed by students, and that make reference to their use in primary schools.

9 Dessin Linéaire et Arpentage, pour touts les écoles primaires, quel que soit le mode d'instruction qu'on y suit, published in 1819. It was translated and adapted to Portuguese by A. F. de P. e Iollanda Cavalcanti d'Albuquerque as Principles of linear drawing comprehending drawing from practical geometry through the monitorial system and published in 1829.
} 
We can state that, for geometry to teach, the concepts contained in manuals that guided teaching practice referred to the subject field of mathematics, more specifically, to Geometry. Such concepts were characterized by straight lines, their relations (parallel, perpendicular), angles, plane geometric figures, circumferences, spatial figures. It is important to observe that the proposed order of teaching contents in the manuals is considered synthetic, for it follows the deductive logic of the scientific field, from the parts to the whole.

On the other hand, geometry for teaching, which characterizes the instruments teachers can use to teach geometry, proved to be strongly attached to free hand drawing practice, that is, the concepts described had to be reproduced by students through copying. For instance, one could learn about equilateral triangles by the practice of reproducing equilateral triangles, the best way possible, by free hand. The role of the teacher (or monitor ${ }^{10}$ ) in the lessons proposed was to correct students' productions (free hand drawings) until a perfect reproduction was achieved. Teachers needed to know the geometric figure in question, its properties and know how to use instruments that validated students' drawings, like rulers, compasses, and protractors.

In the referred example, one was supposed to know that an equilateral triangle has sides and angles of equal measurement. It was geometry for teaching sustained by geometry to teach through its rigorous concepts and through the practice of reproduction as a teaching methodology. Thus, the connection between geometry to teach and geometry for teaching refers, on the one hand, to the fact that teachers know the properties of geometric figures (geometry for teaching); on the other hand, by having knowledge about the properties of geometric figures, teachers will validate the work students produced by free hand (geometry of teaching, geometry to teach).

With respect to normal schools, they were spaces in development in the

\footnotetext{
10 "In individual and simultaneous teaching methods, the teacher is the teaching agent. In the monitorial system, responsibility is shared by the teacher and the monitors, aiming at a democratization of teaching functions" (BASTOS, 1997, p. 117).
} 
$19^{\text {th }}$ century, with an uncertain and turbulent trajectory, subjected to a continuous process of creation and extinction in the various Brazilian provinces (TANURI, 2000). Valente (2011) analyzed Escola Normal de São Paulo (São Paulo Normal School, in free translation) in the end of the $19^{\text {th }}$ century and observed that the Geometry discipline, taught by Professor Godofredo Furtado ${ }^{11}$, constituted deductive geometry, following the order of the theorems to be proved according to geometry's logical-deductive discourse, which was faithful to the referred subject field and had no connection with the aspects of a practical geometry that was taught in schools. Teachers' professional knowledge was linked to the subject field, so knowing Euclidean Geometry was enough for teachers' professional training in normal schools in the $19^{\text {th }}$ century.

The geometric subject field was associated with scientific rigor and with the abstract character of concepts, leaving a mark on future teachers' training. It was Euclidean geometry that prioritized the axiomatic-deductive form. Yet, in the pedagogical field, teaching guidance contained in school manuals pointed to free hand drawing practice, identified by D'Enfert (2007) as a simplified form of Pestalozzi's method, which was based on intuition or on the perception that, once it was like an "art of measurement", it allowed to observe forms, to compare them with geometric figures and represent them through drawings without any need to characterize or define geometric figures, thus constituting intuitive teaching. One might say that, as in arithmetic, the intuitive methodology promoted tension between teacher training and the teaching of intuitive geometry in accordance with new pedagogy.

In comparison to school manuals that guided the teaching of geometry and drawing, the first productions by Brazilian authors date back to the end of the $19^{\text {th }}$ century. Different studies ${ }^{12}$ analyzed the manuals produced in that context, especially considering the books by Borges (1876), Gama (1880), Pacheco (1881) and Freire (1894). The common characteristic to Brazilian

\footnotetext{
${ }^{11}$ Godofredo José Furtado studied Engineering at Escola Central in Rio de Janeiro (VALENTE, 2011).

${ }^{12}$ It is important to mention Guimarães (2017), Leme da Silva (2018a) and Oliveira (2019).
} 
manuals was the insertion of linear drawing, seen as geometric drawing, in which figure constructions are made with the help of instruments like compasses and rulers; nevertheless, for some authors, linear drawing is presented explicitly, whereas, for others, it is implicit.

The content approached in such books, in general, followed the classic organization of Geometry: they started the outlines with plane figures and then presented spatial ones, while they maintained the same teaching order as in books that were translated and adapted. It was a synthetic march: from the parts to the whole. However, unlike in the first works, in which figures were just observed and reproduced, authors inserted the definitions and properties that characterized geometric figures. In this sense, we consider that geometry to teach was not altered; it was preserved and reinforced by its conceptualizations, definitions and properties of Euclidean geometry.

The differentiation is found in the use of instruments, by students, for drawing, because free hand drawing was replaced with geometric drawing. Once more, the foundations for the teaching of geometry in the first years of primary school are provided by drawing. Nevertheless, in the case of geometric drawing, construction instruments were inserted into drawing practice (LEME DA SILVA, 2018a). The methodological tool that backed such orientation was supported by definitions, properties, and sequence of steps to be followed by students for the construction of geometric figures. Geometric drawing of figures and its "recipes" for outlines constituted the tools for teachers' practice, that is, geometry for teaching, linked with memorization. Unlike in the beginning, in which teachers merely assessed students' productions, in geometric drawing, it was necessary for teachers to perform constructions before students reproduced it, as expressed, for instance, in the orientations contained in Borges's (1876) manual.

Oliveira (2019) studied elements of professionality ${ }^{13}$ in Brazilian school

13 The concept of professionality stems from Bourdoncle (1991), Hofstetter and Schneuwly (2009) and André and Almeida (2010) to enable professional development through the 
manuals on linear drawing for primary schools and normal schools in the $19^{\text {th }}$ century and concluded that linear drawing refers to the study of plane figures and polyhedrons and round bodies, and stressed the lack of concern about calculating quantities like perimeter, area and volume. The initial indication of the first public instruction standardization to associate the designation of practical geometry with measurement calculation practices did not happen until the end of the $19^{\text {th }}$ century.

We once more resort to the pedagogy compendium that guided teacher training in normal schools and that was present since the beginning of the intuitive pedagogy: the book by Pontes (1873). Such compendium discusses the subjects that were part of primary school; Geometry and Drawing were present in it, too. In his instructions for teachers, the author highlighted that the approach to the subjects was not supposed to be a bookish or abstract one. Conversely, teachers were not supposed to teach a theorem in itself but to connect it with examples taken from the arts and industry. Such guidelines were given to future teachers as the first steps of professional knowledge.

The Compendium by Silva Pontes proved to be an important document that systematized and advanced professional knowledge from its time: it was a guide "for young men who aspired to teaching" at a time when, to become a teacher, finishing primary school was enough. Immersed in an international context in which the intuitive pedagogy was the most prominent methodology, the book organized mathematics (arithmetic, geometry/drawing) for teaching while keeping it linked to mathematics to teach (MACIEL; VALENTE, 2018).

Even though Calkins's (1886) ${ }^{14}$ manual was not a pedagogy compendium, it had considerable circulation at the time and was considered a

apprehension of rationalized knowledge about the teaching of Geometry or Drawing, and take into consideration contents and their suitability for students in each grade - school level, learning methods, indicated materials and other aspects.

14 The book Primary Object Lessons, for training the senses and developing the faculties of children. A manual of elementary instruction for parents and children, written by Norman Allison Calkins in 1884 and translated into and adapted to Portuguese by Rui Barbosa in 1886. We also refer to studies by Gomes (2011) and Leme da Silva (2015). 
reference for the intuitive methodology, according to Pestalozzi's principles. The book did not contain geometry lessons, but lessons on forms, to observe differences and similarities among geometric figures, in addition to the first lessons on drawing geometric figures by free hand. The author stressed the importance of teachers knowing what to teach, how to teach and when to teach. Thus, the lessons on forms proposed by Calkins were supposed to be developed in a simultaneous work with plane and solid figures (FRIZZARINI; LEME DA SILVA, 2016). The observation of forms, association with children's daily life objects in search of similarities and differences with no need to define them, along with the reproduction of those figures through free hand drawings constituted supporting tools for teachers, that is, Geometry for teaching.

Among pedagogy manuals developed for use in normal schools - that is, to train future primary school teachers -, as previously seen, we find the book Princípios de Pedagogia (1892) (Principles of Pedagogy, in free translation) by Augusto Coelho. Throughout the tomes of Coelho's monumental work, there is the section "Pedagogical presentation of geometric forms and quantitative relations". Forms gained prominence in Coelho's proposition as scientific objects that allowed teachers to work with the elements, transiting from concrete to abstract and vice-versa, in order to apply analytic, synthetic and objective order. It was possible to notice, immediately, that it constituted a systematization of geometry for teaching, which the author named geometry pedagogy, based on Fröebel's work.

Thus, the interweaving between geometry to teach and knowledge for teaching geometry was evident. That is to say, understanding procedural orientations for geometry teaching demanded, necessarily, the mastering of geometry to teach, which can be observed when, for instance, Augusto Coelho instructed teachers to start the study of forms with round solids (spheres, cylinders and cones) and then move to polyhedral solids (hexahedrons, prisms and pyramids), a move that Fröebel did not propose (COELHO, 1892).

An analysis of Augusto Coelho's manual reveals that he considered 
geometry a teaching subject that was established and consolidated in primary school teacher training, given the way the author approached the systematization of "pedagogical presentation of geometric forms", stressing guidelines for the teaching of said subject while considering geometry to teach (FORTALEZA; VALENTE, 2019).

Moreover, there is the manual produced by the principal of Escola Normal de São Paulo (São Paulo Normal School, in free translation), Gabriel Prestes (1895). Prestes highlighted the abstract character of Geometry - a point that makes students' comprehension more difficult -, so he advocated that teaching need to start with what was familiar to and known by children, which did not coincide with the most simple elements in the scientific field, because children's characters are impressed by the objects surrounding them and their notions of lines, areas and volumes. He proposed a practical and intuitive geometry that makes use of cutting, molds and works with overlapping and composition of figures, for example, with surface area measurements (LEME DA SILVA, 2018b).

In terms of references, there is the interaction between different propositions for geometry for teaching. On the one hand, there are works in which the subject field of geometry is prominent, with its definitions, properties and geometric constructions; on the other hand, there are works that highlight the pedagogical field, especially focusing on the intuitive methodology and stressing the observation of similarities and differences among geometric shapes and quantity measurements. All in all, two distinct possibilities to shape the future of teachers who will work with geometry in the first years of primary school.

Tensions between the subject field and education sciences in the growing movement of professionalization in the teaching field seem to be explicit through the comparison between those two types of works that approached teacher training. Some geometry and drawing books stressed the disciplinary character of knowledge; however, pedagogical manuals and 
pedagogical treatises made incursions into various disciplinary fields in order to guide knowledge for teaching.

Another important factor to be pointed and analyzed in the transformation processes of knowledge in geometry teaching and teacher training in the end of the $19^{\text {th }}$ century is the movement to insert the Trabalhos Manuais subject (Handcraft subject, in free translation) into primary school, as well as a subject with the same name in Normal courses, in consonance with the international schooling process of handcraft. Among the several purposes of inserting handcrafts into primary school, we highlight the notion that it could help in teaching other subjects, especially those that involved mathematical knowledge.

Several handcraft activities like modelling, working with cardboard, etc., became part of schools and teacher training, but they presented incipient articulation both in standardization and in the manuals that guided teacher training. Handcraft made use of mathematical concepts (like measurements, angles) so that the resulting crafted objects were similar to plane or spatial geometric figures. Yet, there was no intention of harnessing such objects in the study of their geometric shapes and properties (FRIZZARINI, 2018).

The works that stressed the emerging pedagogy revealed that the elaboration of knowledge for teaching was in progress, for there were teaching propositions that inserted pedagogy into disciplinary knowledge. Therefore, it is possible to consider that they presented pedagogy for geometry and systematized mathematics for teaching said subjects, which characterized intuitive geometry, i.e., geometry for teaching. The arrival of a new pedagogical - Progressive Education - brought a new configuration to the processes and dynamics of elaboration of knowledge for teaching.

With the international Progressive Education movement, it was possible to identify deeper concerns about teacher formation, teaching methods and processes, and there was a desire for accelerating the process of teaching professionalization. Institutions were created and reforms were performed in 
Brazilian states in order to spread innovative propositions based on Progressive Education discussions, which definitively left a mark on the culture of normal education, especially regarding the insertion and appreciation of professional knowledge for teaching practice. Such institutions assumed different characteristics in each state, but their common characteristic was the focus on what we can call mathematics for teaching (OLIVEIRA et al., 2016).

Thus, the tensions between disciplinary and pedagogical fields revealed by the conflict between the different materials, that is, teaching manuals versus pedagogical manuals - rose to a higher level. References for teacher training were reconfigured and there was the emergence of teaching manuals according to special methodologies for the teaching of different subjects like arithmetic, geometry and others.

Therefore, there was a noticeable transition: from a pedagogy of geometry and drawing, contained in pedagogical treatises, to a geometry and drawing methodology, which was systematized in the works that approached special didactics for teacher training.

The pedagogy characterized as Progressive Education caused reconfigurations in the teaching propositions for the Geometry subject in primary school. The presence of geometric drawing linked to the teaching of geometry remained, but it started to lose strength. Some studies provide us with indicators for that change.

The state of São Paulo created a subject called Formas (Shapes, in free translation) for the first two years of primary school and moved Geometry to the third and fourth years. The Formas subject embraced the propositions from Handcraft when it encouraged students to handle and construct geometric figures and solids, characterized as experimental Geometry. The Geometry subject delved deeper into concepts, encouraged constructions with instruments and developed notions of area and volume, which was defined as conceptual geometry (FRIZZARINI, 2014). It seems that what was previously considered geometry for teaching - attention to shapes - later became geometry to teach: 
shapes as a teaching subject.

During the Progressive Education movement, Handcraft constituted a fertile field for the systematization and consolidation of what had been taught in other subjects in the previous historical period, when the intuitive method was the prominent methodology. There was a dissociation of Handcraft all over the subjects that composed the primary course, like Shapes, Geometry, Drawing, Arithmetic and Mathematics. For instance, the geometric solids were recognized and characterized through modelling and working with cardboard (FRIZZARINI, 2018).

An analysis of such materials - geometry and drawing books, special methodologies, standardizations and pedagogical journals - allows us to say that, all in all, in the first half of the $20^{\text {th }}$ century, geometric drawing drifted away from geometry teaching until it disappeared from regulations, whereas Handcraft increasingly gained prominence with the Progressive Education movement. Seemingly, performing handcraft took on the role of geometry for teaching as a supporting tool for the teaching of geometry. It constituted new professional knowledge: teachers were trained to know how to do it, which enabled them to teach the first steps of geometry in the beginning of children's school life.

The insertion of handcraft into geometry teaching also altered geometry to teach, which remained a study of geometric shapes, but broke up with the synthetic content order (from plane to space) applied until then. The practice of handling and building molds and observing daily-life objects used solids as a starting point, and followed with the observation of faces and lines, that is to say, an analytic order was adopted (from the whole to the parts).

Another element that significantly contributed to changing geometry to teach was the concentric circles method - appropriated by Heitor Lyra (1923) -, which privileged experience rather than the classic method, thus compelling the articulation of studying planes and space throughout his proposition, without following a single direction, whether it was synthetic or analytic. (SILVA; LEME 
DA SILVA, 2019). It is important to revisit Coelho's (1892) instructions, which suggested an order for the teaching of geometric shapes - analytic, synthetic and objective. Here, this instruction is interpreted as concentric circles.

Geometry to teach started to undergo a transformation due to demands from geometry for teaching and, therefore, drifted away from the scientific field and approached pedagogical instructions. It was in constant movement, ruled by situations of practical order, which gathered together, aiming at specific knowledge about geometry teaching, especially a movement involving the study of plane and spatial figures without following the logical deductive order of Euclidean geometry.

On the other hand, geometry for teaching was also remodeled according to the dynamics of answers to the knowledge in question and continued to have drawing as an important ally, but no longer as geometry for teaching. In its place, tridimensional objects - both daily objects and objects constructed by children for the study of geometry - are prioritized. The relevance of the Decroly method, which revolved around Centers of Interest - a pedagogical concept that emphasizes global teaching processes -, stressed the valorization of tridimensional objects in the face of drawing.

In short, the construction of a new geometry for teaching may be inferred. It was distant from the referential science of Euclidean geometry and configured a long process in the history of mathematics education. Its first steps arose from the intuitive method, with the major importance of its pedagogical manuals in the systematization of what could be identified as "pedagogy of the intuitive method to teach geometry and drawing”. Afterwards, with the progress of the teaching professionalization movement at the time of Progressive Education, there was the prominence of the development of subjects for teacher training based on special methodologies: the methodology of arithmetic, of drawing, etc. It was a systematization for the teaching of geometry and drawing, not in a broad way as a pedagogy, but as a methodology for the teaching of such subjects. 


\section{CONCLUSION}

The analyses performed in this chapter constitute reflections about results from research on the transformations in mathematics teaching in primary school and on the mathematics harnessed in teacher training, in the collective research projects sphere. From the perspective of theoretical advancements on such theme, there is emphasis on understanding the relationships between the mathematical subject field and pedagogy in terms of teaching and teacher training for primary school. It is necessary to highlight that studies have been corroborating the hypothesis that the relationships between the two fields produce mathematics of different natures - mathematics to teach and mathematics for teaching.

The study of the transformations undergone by arithmetic, geometry and drawing revealed that until the end of the $19^{\text {th }}$ century, such subjects were configured the same way: knowledge to teach and knowledge for teaching were equally referenced by the mathematics disciplinary field, with little reference to pedagogical guidelines. Arithmetic, geometry and drawing treatises used in teacher training are documents that, to a large extent, empirically confirm such conclusion.

When modern pedagogy emerged in the final decades of the $19^{\text {th }}$ century, such landscape changed. Mathematics (arithmetic, geometry, drawing) to teach and mathematics (arithmetic, geometry, drawing) for teaching arose with more visible specificities. Teachers' new professional knowledge - regarding mathematics - was characterized in a markedly different way from the one contained in the treatises on various secondary school subjects (treatises on arithmetic, geometry, etc.). Thus, future teachers were supposed to harness multiple elements for the exercise of their profession, that is, the teaching of intuitive mathematics. With the treatises on mathematics as references for teacher training, new books and processes came along: modelling, cardboard work, letters and maps with intuitive games, a wide range of concrete materials (as in modelling, cardboard, seeds, sticks, miniature lathes, etc.), 
instruments for teaching drawing, new books containing pictures to be used in the intuitive mathematics teaching process, etc.

To a large extent, the tensions between the mathematics subject field and pedagogy could be analyzed by observing treatises on mathematics and pedagogy works. In the former, mathematics to teach was highlighted; in the latter, mathematics for teaching gained prominence. There was the configuration of a pedagogy of mathematics, specifically placed in the guidelines contained in pedagogy works for teacher training.

It did not take long before such professional knowledge - the interaction between intuitive mathematics (arithmetic, geometry and drawing) and intuitive mathematics (arithmetic, geometry and drawing) for teaching proved to be inappropriate in the face of advancements in pedagogy, which had acquired the status of a scientific field - Scientific Pedagogy, Progressive Education. Teachers had to be trained according to results from statistically based experimental psychology.

Teacher training courses faced a new challenge of elaborating knowledge for training future teachers so that they were able to teach based on the new psychology, which caused ruptures with the intuitive concept. New knowledge regarding that new mathematics was developed, and there was a transition from a pedagogy of mathematics to discussions on special methodologies. The former was synthetized when the intuitive pedagogy prevailed; methodologies for mathematics made way for the objectivization of new knowledge presented in works like methodologies of arithmetic, of geometry, etc.

The late 1950s saw new and profound transformations in school mathematics, that is, in mathematics to teach and in mathematics for teaching. Changes largely happened through a revolution in the disciplinary field. Mathematics as a scientific field was in the midst of major changes: structuralism started to configure all scientific productions, which encompassed mathematics, and the school environment was surely not immune to such 
changes. The New Mathematics Movement 15 emerged. Changes were so dramatic that teacher training would no longer prioritize arithmetic - algebra started studies in teacher training and in teaching. The Set Theory became new professional knowledge.

\section{REFERENCES}

BASTOS, Maria Helena Camara. A instrução pública e o ensino mútuo no Brasil: uma história pouco conhecida (1808-1827). Revista História da Educação, Pelotas, n. 1, p. 115-133, abr. 1997.

BERTINI, Luciane de Fatima; MORAIS, Rosilda dos Santos; VALENTE, Wagner Rodrigues. A matemática a ensinar e a matemática para ensinar novos estudos sobre a formação de professores. São Paulo: L. F. Editorial, 2017.

CHARTIER, Roger. A história cultural: entre práticas e representações.

Lisboa: Difel; Rio de Janeiro: Bertrand Brasil S. A., 1990.

CHERVEL, André. História das disciplinas escolares: reflexões sobre um campo de pesquisa. Revista Teoria \& Educação, Porto Alegre/RS, n. 2, p. 177-229, 1990.

CHOPPIN, Alan. O manual escolar: uma falsa evidência histórica. Translated by Maria Helena C. Bastos. Revista História da Educação, Pelotas, v. 13, n. 27, p. 09-75, jan./abr. 2009.

COELHO, José Augusto. Principios de pedagogia. Tomo I. São Paulo: Teixeira \& Irmão Editores, 1891.

COELHO, José Augusto. Principios de pedagogia. Tomo II. São Paulo: Teixeira \& Irmão Editores, 1892.

D’ENFERT, Renaud. Uma nova forma de ensino de desenho na França no início do século XIX: o desenho linear. Translated by Maria Helena Câmara Bastos. Revista História da Educação, Pelotas, n. 22, p. 31-59, maio 2007.

FORTALEZA, Francisca Janice; VALENTE, Wagner Rodrigues. Uma geometria para ensinar no curso primário: elementos do saber profissional e o manual de

${ }_{15}$ For further studies on the New Mathematics Movement, see Oliveira; Leme da Silva; Valente (2011). 
pedagogia de José Augusto Coelho (1892). Revista Vidya, Santa Maria/RS, v. 39, n. 2, p. 347-361, jul./dez. 2019.

FRIZZARINI, Claudia Regina Boen. Do ensino intuitivo para a escola ativa: os saberes geométricos nos programas do curso primário paulista. 2014. 160 f. Dissertation (Master's Degree) - Programa de Pós-Graduação em Educação e Saúde na Infância e na Adolescência, Universidade Federal de São Paulo, Guarulhos, 2014.

FRIZZARINI, Claudia Regina Boen. Saberes matemáticos na matéria Trabalhos Manuais: processos de escolarização do fazer, São Paulo e Rio de Janeiro (1890-1960). 2018. 184 f. Thesis (Doctorate) - Programa de PósGraduação em Educação e Saúde na Infância e na Adolescência, Universidade Federal de São Paulo, Guarulhos, 2018.

FRIZZARINI, Claudia Regina Boen; LEME DA SILVA, Maria Célia. Saberes geométricos de Calkins e sua apropriação nos programas de ensino dos grupos escolares paulistas. Revista Brasileira de História da Educação, Maringá/PR, v. 16, n. 3 (42), p. 10-35, jul./set. 2016.

GOMES, Maria Laura Magalhães. Lições de coisas: apontamentos acerca da geometria no manual de Norman Allison Calkins (Brasil, final do século XIX e início do XX). Revista Brasileira de História da Educação, v. 11 (26), p. 53-80, 2011.

GUIMARÃES, Marcos Denilson. Porque ensinar desenho no curso primário? Um estudo sobre as suas finalidades (1829-1950). 2017. $213 \mathrm{f}$. Thesis (Doctorate) - Programa de Pós-Graduação em Educação e Saúde na Infância e na Adolescência, Universidade Federal de São Paulo, Guarulhos, 2017.

HOFSTETTER, Rita; SCHNEUWLY, Bernard; FREYMOND, Mathilde de; BOS, François. Penetrar na verdade da escola para ter elementos concretos de sua avaliação - A irresistível institucionalização do expert em educação (século XIX e XX). In: HOFSTETTER, Rita; VALENTE, Wagner Rodrigues (org.). Saberes em (trans)formação: tema central da formação de professores. São Paulo: Livraria da Física, 2017. p. 55-112.

HOFSTETTER, Rita; VALENTE, Wagner Rodrigues (org.). Saberes em (trans)formação: tema central da formação de professores. São Paulo: Livraria da Física, 2017.

LEME DA SILVA, Maria Célia. Calkins' primary object lessons: practices for drawing and measuring. International Journal for Research in 
Mathematics Education, v. 5, p. 91-104, 2015.

LEME DA SILVA, Maria Célia. História da Educação Matemática e a formação de professores: ensino de medidas. Cadernos de História da Educação, v. 17, n. 1, p. 245-259, jan./abr. 2018b.

LEME DA SILVA, Maria Célia. Práticas de desenho e saberes geométricos nos manuais escolares do século XIX. Pro-Posições, v. 29, n. 2 (87), p. 352-369, maio/ago. 2018a.

LEME DA SILVA, Maria Célia; VALENTE, Wagner Rodrigues (org.). A geometria nos primeiros anos escolares: história e perspectivas atuais. Campinas, SP: Papirus, 2014.

MACIEL, Viviane Barros. Elementos do saber profissional do professor que ensina matemática: uma aritmética para ensinar nos manuais pedagógicos (1880-1920). 2019. 312 f. Thesis (Doctorate) - Programa de PósGraduação em Educação e Saúde na Infância e na Adolescência, Universidade Federal de São Paulo, Guarulhos, 2019.

MACIEL, Viviane Barros; VALENTE, Wagner Rodrigues. Elementos do saber profissional do professor que ensina matemática: o Compêndio de Pedagogia de Antônio Marciano da Silva Pontes. Amazônia - Revista de Educação em Ciências e Matemáticas, 2018.

OLIVEIRA, Marcus Aldenisson de. A aritmética escolar e o método intuitivo: um novo saber para o curso primário, 1870-1920. 2017. Thesis (Doctorate) - Programa de Pós-Graduação em Educação e Saúde na Infância e na Adolescência, Universidade Federal de São Paulo, Guarulhos, 2017.

OLIVEIRA, Maria Cristina Araújo. O desenho e a profissionalidade dos professores primários no século XIX. Zetetiké, Campinas/SP, v. 27, p. 1-14, 2019.

OLIVEIRA, Maria Cristina Araújo; FISCHER, Maria Cecília Bueno; RIOS, Diogo Franco; SIQUEIRA FILHO, Moyses Gonçalves; WIELEWSKI, Gladys Denise; FRANÇA, Iara da Silva; SILVA, Martha Raíssa Iane Santana; BARROS, Silvia de Castro; PEZZIN, Ana Claudia; PATROCÏNIO, Margarida Célia; MELLO, Mélany dos Santos. A matemática na formação de normalistas. In: PINTO, Neuza Bertoni; VALENTE, Wagner Rodrigues (org.). Saberes matemáticos em circulação no Brasil dos documentos oficiais às revistas pedagógicas, 1890-1970. São Paulo: Editora Livraria da Física, 2016. p. 187-243.

OLIVEIRA, Maria Cristina Araújo; LEME DA SILVA, Maria Célia; VALENTE, 
Wagner Rodrigues. O Movimento da Matemática Moderna: história de uma revolução disciplinar. Juiz de Fora: Editora UFJF, 2011.

PINHEIRO, Nara Vilma Lima. A aritmética sob medida: a matemática em tempos da pedagogia científica. 2017. $223 \mathrm{f}$. Thesis (Doctorate) - Programa de Pós-Graduação em Educação e Saúde na Infância e na Adolescência, Universidade Federal de São Paulo, Guarulhos, 2017.

PONTES, Antonio Marciano da Silva. Compendio de pedagogia: para uso dos alumnos da escola normal da Provincia do Rio de Janeiro. Rio de Janeiro: Typ. da Reforma (1873), 1881.

SILVA, Circe Mary Silva da; LEME DA SILVA, Maria Célia. Observação e experiência como fio condutor da geometria de Heitor Lyra da Silva. Zetetiké, Campinas/SP, v. 27, p. 1-18, 2019.

SILVA, Vivian Batista. Saberes em viagem nos manuais pedagógicos: construções da escola em Portugal e no Brasil (1870-1970). 2005. 399 f. Thesis (Doctorate) - Faculdade de Educação, Universidade de São Paulo, 2005.

TANURI, Leonor Maria. História da formação de professores. Revista Brasileira de Educação, n. 14, p. 61-88, mai./jun./jul./ago. 2000.

VALENTE, Wagner Rodrigues. A matemática na formação do professor do ensino primário em São Paulo (1875-1930). São Paulo:

Annablume/Fapesp, 2011.

VALENTE, Wagner Rodrigues. Tempos de Império: a trajetória da geometria como um saber escolar para o curso primário. Revista Brasileira de História da Educação, v. 12, p. 73-94, 2012.

WAGNER RODRIGUES VALENTE é Professor Adjunto Livre Docente do Departamento de Educação da Escola de Filosofia, Letras e Ciências Humanas da Universidade Federal de São Paulo (Unifesp), Campus Guarulhos, SP (2010). Doutor em Educação pela Faculdade de Educação da Universidade de São Paulo e INRP - Institut National de Recherche Pédagogique de Paris (1997). Mestre em História e Filosofia da Educação pela Pontifícia Universidade Católica de São Paulo (1991). Graduado em Engenharia pela Escola Politécnica da Universidade de São Paulo (1979). Presidente do Grupo Associado de Estudos e Pesquisas sobre História da Educação Matemática Ghemat Brasil (ghemat-brasil.com) (gestão 2018-2021).

E-mail: ghemat.contato@gmail.com 
http://orcid.org/0000-0002-2477-6677

MARIA CÉLIA LEME DA SILVA é Professora Associada do Departamento de Física do Instituto de Ciências Ambientais, Químicas e Farmacêuticas da Universidade Federal de São Paulo (Unifesp), Campus Diadema, SP. Realizou estágio pós-doutoral na Universidade Nova de Lisboa (2006) e na Université Paris 11 (2015). Doutora em Educação (Currículo) pela Pontifícia Universidade Católica de São Paulo (2002). Mestre em Educação Matemática pela Pontifícia Universidade Católica de São Paulo (1997). Graduada e Licenciada em Matemática pela Pontifícia Universidade Católica de São Paulo (1988). Pesquisadora do GHEMAT - Grupo de Pesquisa em História da Educação Matemática no Brasil desde 2005.

E-mail: celia.leme@unifesp.br

(1) http://orcid.org/0000-0001-6029-0490

Recebido em: 02 de janeiro de 2020

Aprovado em: 18 de março de 2020

Revista História da Educação - RHE

Associação Sul-Rio-Grandense de Pesquisadores em História da Educação - Asphe

Artigo de acesso aberto distribuído nos termos de licença Creative Commons. 